\title{
Lumbar pseudomeningocele following blunt trauma without spinal fractures
}

\author{
José Alberto Gonçalves da Silva', Adailton Arcanjo dos Santos Junior ${ }^{2}$ \\ Hospital Unimed, Department of Neurosurgery, João Pessoa, PB, Brazil.
}

\begin{abstract}
The lumbar pseudomeningocele (PSM) is an uncommon condition, mainly, after a lumbar blunt trauma. The authors present a rare case of PSM following a lumbar blunt trauma which did not show any abnormalities in the magnetic resonance imaging (MRI) of the lumbar region. Firstly, the patient underwent to conservative treatment that fail and then it was performed a surgical approach of the lumbar area, however, the lumbar fluid collection appeared again and a lumboperitoneal shunt (LPS) was then performed with complete successful. One year and half afterwards the LPS the patient continues asymptomatic. The standard treatment of this condition remains uncertain, but the conservative treatment followed by LPS is a good option and can be done in several cases.
\end{abstract}

\section{KEYWORDS}

Meningocele, spinal injuries, lumbosacral region, fistula.

\section{RESUMO}

Pseudomeningocele lombar após trauma fechado sem fraturas vertebrais

A pseudomeningocele lombar é uma condição incomum, principalmente após trauma lombar fechado. Os autores apresentam um caso raro de pseudomeningocele lombar após trauma lombar fechado que não apresentou alterações na ressonância magnética da região lombar. Primeiramente, o paciente foi submetido ao tratamento conservador que falhou, sendo submetido, em seguida, à abordagem cirúrgica da região lombar, entretanto, a coleção lombar fluida apareceu novamente, sendo, então, realizada uma derivação lomboperitoneal com remissão completa da coleção. Um ano e meio após a derivação lomboperitoneal, o paciente permanece assintomático. O tratamento padrão dessa patologia ainda permanece incerto, mas o tratamento conservador seguido de derivação lomboperitoneal é uma boa opção e pode ser feito em certos casos.

\section{PALAVRAS-CHAVE}

Meningocele, traumatismos da coluna vertebral, região lombossacral, fístula. 


\section{Introduction}

Pseudomeningocele is an epidural cerebrospinal fluid (CSF) collection that is resulted from the communication between the subarachnoid space and the adjacent tissues, as well as with another body cavity. From the etiopathogenic aspect, PSM is divided into 3 types: iatrogenic, congenital and traumatic. ${ }^{1}$ PSM is an uncommon clinical condition, most of the cases are predominantly iatrogenic and postoperative. Posttraumatic cases are rare and they are usually resulted from dural breach or nerve root avulsion..$^{2-4}$ Diagnosis is based on the clinical presentation associated with the imaging findings. A few cases of PSM are asymptomatic, however, some signs and symptoms are associated with the existence of PSM such as fluid mass that augment with valsalva maneuver, low-back pain and radiculopathy.

Other less common symptoms are posture-related headache, cervical pain, nausea, vomiting, photophobia and myelopathy. ${ }^{5}$ Some diagnostic exams can help in the PSM diagnosis, however, magnetic resonance imaging (MRI) is considered the neuroimaging gold standard tool. PSM diagnosis is based on clinical features and imaging findings after surgical procedure or traumatism in the lumbar region.

The gold standard treatment for PSM has been currently debated and there is a variety of PSM approaches. Most authors propose the conservative management as the initial approach by bed rest, Trendelemburg position and the use of corset brace to compress the area of the PSM. McCallum et al. ${ }^{6}$ had a good response to repeated lumbar punctures for two or three days along with Trendelemburg position. In case of failure of the conservative treatment, other methods can be useful such as epidural blood patch and closed lumbar subarachnoid drainage. ${ }^{7}$ Surgical treatment for dural repair or LPS placement are used whether conservative management fails.

\section{Case report}

A 48-year-old man presented a painful fluid mass in the lumbar area three days after a fall when he was riding a horse. Additionally to the beginning of the clinical onset he referred a moderate low-back pain that radiated down to the left leg until the ankle and presented no sensitive sign. Punction of the fluid mass was carried out and the aspirated liquid had a bloody-serous aspect. Few days afterwards this puncture, the patient presented another fluid mass with similar characteristics. X-ray of lumbar spine did not show any abnormalities.
The MRI depicted a delimited subcutaneous fluid collection with low signal intensity on $\mathrm{T}_{1}$-weighted images and high signal on $\mathrm{T}_{2}$-weighted images as well as no spinal fractures (Figure 1A-B). After 16 days of unsuccessful conservative treatment, through bed rest, surgical procedure was indicated through an open drainage of the CSF collection associated with a tight closure of the adjacent tissues. During that procedure it was not possible to find the exact location of the CSF fistula. Despite the partial relief of the low-back pain, the patient presented another lumbar collection two days after this procedure. On this occasion, a LPS was then performed resulting in progressive improvement of the low-back pain, sciatica and remission of the CSF collection. After one year and half of follow up, the patient continues asymptomatic.
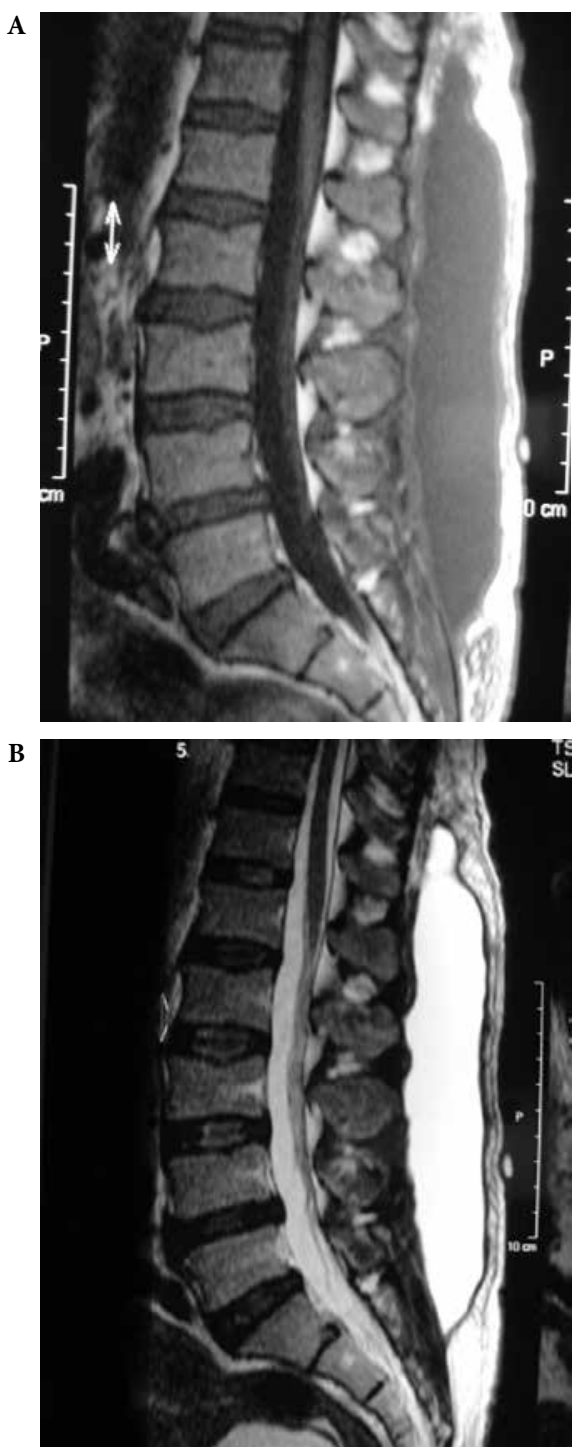

Figure 1 - Sagittal MRI showing a delimited subcutaneous fluid collection with low signal intensity on T1-weighted images (A) and high signal on T2-weighted images (B) as well as no spinal fractures. 


\section{Discussion}

PSM is an infrequent clinical condition particularly secondary to blunt trauma whose true incidence is unknown. ${ }^{1-10}$ According to the literature, there is some evidence that traumatic PSM are due to fractures or bony dislocations, or still, nerve root injury. ${ }^{2,11,12}$ Couture and Branch ${ }^{10}$ described the existence of rare cases in the literature of PSM following blunt trauma which they were not related to nerve root injury.

This study reports a rare case of lumbar PSM following blunt trauma, without spinal fracture.

The exact pathophysiological mechanisms that underlie the formation and maintenance of the PSM remains uncertain. However, the presence of dural breach is obligatory to the PSM formation. Many theories have been presented to explain the genesis of PSM. According to Teplick et al. apud Hawk and Kim, ${ }^{5}$ when intact arachnoid herniates throughout the dura mater, the dural breach occurs and remains open what promote the formation of PSM. When an arachnoidal injury occurs, it is more likely that the communication will close. However, Tsuji et al. apud Hawk and Kim, ${ }^{5}$ suggested that the volume of the leaked fluid is the most important etiological factor to develop PSM. If CSF leak is small, the fluid is easier absorbed and the lesion is selflimited. McLennan et al. apud Barberá et al., ${ }^{13}$ referred that small dural breaches have a higher probability in developing PSM, because its ball-valve mechanism that allows a one-way flow of the CSF fistula.

In the present report, there was no evidence of fracture or bony dislocation which could explain a direct dural injury or lumbar nerve root avulsion. The possible pathophysiological mechanisms to explain the formation of PSM is that a small dural tear occurred and might have functioned as a ball-valve mechanism, as mentioned previously by McLennan.

Diagnosis of PSM is based on the clinical features complemented by the neuroimaging findings, especially the MRI. ${ }^{14,15}$ LPS is considered as a method that should only be used after failure of surgical repair. ${ }^{5}$ However, some reports show success with the use of LPS in cases of CSF fistula ${ }^{2,16}$ and traumatic PSM, ${ }^{3}$ as reported at this present study.

\section{Competing interests}

The authors declare that they have no competing interests.

\section{References}

1. Cook DA, Heiner JP, Breed AL. Pseudomeningocele following spinal fracture. A case report and review of the literature. Clin Orthop Relat Res. 1989;(247):74-9.

2. Barnett HG, Connolly ES. Lumbosacral nerve root avulsion: report of a case and review of the literature. J Trauma. 1975;15(6):532-5.

3. Kitchen $\mathrm{N}$, Bradford R, Platts A. Occult spinal pseudomeningocele following a trivial injury successfully treated with a lumboperitoneal shunt: a case report. Surg Neurol. 1992;38(1):46-9.

4. Schumacher HW, Wassmann H, Podlinski C. Pseudomeningocele of the lumbar spine. Surg Neurol. 1988;29(1):77-8.

5. Hawk MW, Kim KD. Review of spinal pseudomeningoceles and cerebrospinal fluid fistulas. Neurosurg Focus. 2000;9(1):e5.

6. McCallum JE, Tenicela R, Jannetta PJ. Closed external drainage of cerebrospinal fluid in treatment of postoperative csf fistulae. Surg Forum. 1973;24:465-7.

7. McCormack BM, Taylor SL, Heath S, Scanlon J. Pseudomeningocele/CSF fistula in a patient with lumbar spinal implants treated with epidural blood patch and a brief course of closed subarachnoid drainage. A case report. Spine (Phila Pa 1976). 1996;21(19):2273-6.

8. Aoki N. Lumboperitoneal shunt for the treatment of postoperative persistent collection of subcutaneous cerebrospinal fluid (pseudomeningocoele). Acta Neurochir (Wien). 1989;98(1-2):32-4

9. Aoki N. Lumboperitoneal shunt: clinical applications, complications, and comparison with ventriculoperitoneal shunt. Neurosurgery. 1990;26(6):998-1003.

10. Couture D, Branch CL Jr. Spinal pseudomeningoceles and cerebrospinal fluid fistulas. Neurosurg Focus. 2003;15(6):E6.

11. Carlson DH, Hoffman HB. Lumbosacral traumatic meningocele. Report of a case. Neurology. 1971;21(2):174-6.

12. Hadley MN, Carter LP. Sacral fracture with pseudomeningocele and cerebrospinal fluid fistula: case report and review of the literature. Neurosurgery. 1985;16(6):843-6.

13. Barberá J, Broseta J, Argüelles F, Barcia-Salorio JL. Traumatic lumbosacral meningocele. Case report. J Neurosurg. 1977;46(4):536-41.

14. Freedy RM, Miller KD Jr, Eick JJ, Granke DS. Traumatic lumbosacral nerve root avulsion: evaluation by MR imaging. J Comput Assist Tomogr. 1989;13(6):1052-7.

15. Hans FJ, Reinges $\mathrm{MH}$, Krings $\mathrm{T}$. Lumbar nerve root avulsion following trauma: balanced fast field-echo MRI. Neuroradiology. 2004;46(2):144-7.

16. James HE, Tibbs PA. Diverse clinical applications of percutaneous lumboperitoneal shunts. Neurosurgery. $1981 ; 8(1): 39-42$.

Correspondence address

José Alberto Gonçalves da Silva

Av. Minas Gerais, 1150

58030-092 - João Pessoa, PB, Brazil

E-mail: jags1803@hotmail.com

Adailton Arcanjo dos Santos Júnior

Rua Martiniano de Carvalho, 880, ap. 62

01321-000 - São Paulo, SP, Brazil

Telefone: (055 11) 96549-3575

E-mail: adailtonarcanjo@yahoo.com.br 